\title{
The Effectiveness of Behavioral Counseling with Modeling Techniques to Improve Student Self-Achievement
}

\author{
I Ketut Dharsana $^{\left.1^{*}\right)}$, Wayan Eka Paramartha ${ }^{2}$ \\ ${ }^{12}$ Universitas Pendidikan Ganesha \\ *Corresponding author, e-mail: iketut.dharsana@undiksha.ac.id
}

Received May 30, 2021; Revised May 31, 2021;

Accepted June 02, 2021;

Published Online 2021-06-03

\section{Conflict of Interest} Disclosures:

The authors declare that they have no significant competing financial, professional or personal interests that might have influenced the performance or presentation of the work described in this manuscript.

\begin{abstract}
This study aims to determine the difference between before and after treatment and to determine the effect of behavioral counseling with modeling techniques to improve student self-achievement. The research was conducted at SMK Negeri 1 Singaraja in class X, and used a randomized controlled trial (RCT) research design. Sampling in this study through simple random sampling which took 2 research samples, namely the experimental and control classes. The results of this study indicate the influence of behavioral counseling with modeling techniques to increase self-achievement through the effect size test. Based on these results, the researcher recommends behavioral counseling with modeling techniques to increase self-achievement in school.
\end{abstract}

Keywords: Behavioral Counseling, Modeling, Self Achievement.

Indonesian Abstract: Penelitian ini memiliki tujuan untuk mengetahui perbedaan antara sebelum dan sesudah diberikan treatment serta untuk mengetahui pengaruh dari konseling behavioral dengan teknik modeling untuk meningkatkan self achievement siswa. Penelitian dilakukan di SMK Negeri 1 Singaraja pada kelas X, dan menggunakan desain penelitian Randomised Controlled Trials (RCT). Pengambilan sampel dalam penelitian ini melalui simple random sampling yang mengambil 2 sampel penelitian yaitu kelas eksperimen dan kontrol. Hasil penelitian ini menunjukkan adanya pengaruh konseling behavioral dengan teknik modeling untuk meningkatkan self achievement melalu uji effect size. berdasarkan hasil tersebut maka peneliti merekomendasikan konseling behavioral dengan teknik modeling untuk meningkatkan self achievement di sekolah.

Kata Kunci: Konseling Behavioral, Modeling, Self Achievement.

How to Cite: I Ketut Dharsana, Wayan Eka Paramartha. 2021. The Effectiveness of Behavioral Counseling with Modeling

Techniques to Improve Student Self-Achievement. Bisma, 5 (1): pp. 44-48, DOI: http://dx.doi.org/10.23887/bisma.v4i1

\section{Introduction}

Character education is very necessary for students, especially in obtaining honesty values. This character development is the first step for a future life (IDharsana, Paramartha, \& Sudarsana, 2018). Reaching goals is part of the achievement that every individual wants. The achievement is obtained through the abilities they have. Besides that, one's ability to achieve success is obtained with certain skills and skills, especially in the learning process. 
The phenomenon encountered by researchers in practicing in schools is mainly in learning activities. Researchers made observations found that $65 \%$ of students had symptoms that led to a lack of student motivation. Through interviews it was found $62 \%$, in the results of diary monitoring there were $68 \%$, and in the results of the questionnaire there were $74 \%$ having symptoms that led to a lack of student motivation to excel. Based on the data obtained, it can be interpreted as students who experience low self-achievement. Based on the expert opinion above, the researcher refers to the expert Dharsana's definition which states that self-achievement is a person's ability to achieve the success desired by each individual with certain expertise in the learning process through completing tasks well and more than anyone else. The indicators obtained from the above definition are as follows: 1) able to complete tasks well, 2) able to complete tasks with certain skills, 3) doing tasks well more than anyone else (Paramartha, Dharsana, \& Suarni, 2017).

McCleland defines nAchievement as success in competition with several standards of excellence (Acquah, 2017). This shows that the objectives of some individuals to compete have a standard of excellence. Through excellence standards, individuals may experience failure, but individuals are still able to identify goals in achieving the desired. Counseling is given to clients with the aim of dealing with dysfunctional interpretations. The counselor is intended to be able to change the client's cognitive processes and wrong assumptions (I. K. Dharsana, 2019). In behavior change there is still a cognitive process in it (I. K. Dharsana, Suarni, Sudarsana, Paramartha, \& Mardiana, 2019).

Behavioral is behavior that includes a difficult subject, not because it is inaccessible but because this behavior is very complex (Skinner, 1976). Behavioral counseling is also often known as behavior modification, which means that every action is aimed at changing individual behavior (Mahendra, Dharsana, \& Suarni, 2019). Behavioral theory has several approaches, namely gestalt, social learning, reality, etc. This model is still within the scope of the behavioral approach, which concerns problems related to individual behavior. Albert Bandura came up with a modeling method through a social learning model. This social learning modeling process occurs when individuals imitate through their social environment. Social learning also generally refers to learning through observation, because the knowledge that individuals get is the result of doing these observations (Zhou, College, Brown, \& College, 2015). Modeling techniques are one of the techniques that can be used in the counseling process where a person learns to apply new behaviors through the process of observing the behavior of others (models), where in this modeling also involves cognitive processes that are not merely imitation done (K.Dharsana, 2017 ). Albert Bandura said that there are 4 conditions that are needed in the modeling process (imitation). Through consideration of these steps, each individual is able to successfully model the behavior of others. These steps include: 1) Attention, 2) Remembering, 3) Imitation, 4) Motivation (Nabavi, 2014). Modeling does not only imitate or follow what the model does, but individuals observe the behavior of the model so that it involves cognitive processes in it (Imran, Suarni, \& Darsana, 2019). Based on the description above, the researcher has an interest in studying research which takes the topic "The Effect of Behavioral Counseling with Modeling Techniques to Improve Student Self Achievement".

The purpose of this study is also in accordance with the formulation of the problem above, namely: 1) to determine the significant difference in self-achievement between before and after attending behavioral counseling with modeling techniques, 2) to determine the effect of behavioral counseling with modeling techniques on student self achievement. The benefits of this research are expected to readers to add insight and knowledge related to behavioral counseling with modeling techniques to increase student selfachievement, and for researchers to hone the researcher's ability to conduct behavioral counseling with modeling techniques to improve student self-achievement.

\section{Method}

The design of this study used a quasi-experimental type with a randomized controlled trial (RCT) design. This design does random selection to determine the sample as a study. After the random selection was made and the control and experimental groups were determined. Then carried out the distribution of the pretest to the research sample. Then given the treatment.

The treatment was only carried out in the experimental group. Through the provision of these treatments, the researcher carried out a posttest distribution to determine the effect of the treatment that had been given. After that, followed up 2 times to find out the outcome of this study (Jadad, 1998). 
The population in this study were all students of class X SMK Negeri 1 Singaraja, amounting to 12 classes with approximately 435 students. Sampling in this study was carried out by means of random sampling, by taking 2 classes which were used as the experimental class and the control class. The study was conducted approximately 8 meetings providing pretest, posttest, treatment, follow-up 1 and follow-up 2 . This data collection method is obtained through the results of observations made, interviewing a number of students, a self-achievement questionnaire, and providing a diary.

The diary is given to students and is monitored at any time. Data analysis used SPSS version 21 Windows 10 , starting from testing the validity and reliability of the questionnaire. Then perform the prerequisite test in the form of a normality test and a homogeneity test. The last stage is to test the hypothesis with the t-test through the independent sample test and use the effect size formula to find out how effective the research was.

\section{Results and Discussion}

The results of this study were found based on observations of $65 \%$ showing symptoms of low selfachievement. The results of the interviews showed $62 \%$, in the results of daily diary monitoring there were $68 \%$, and the results of the questionnaire showed that $74 \%$ had low self-achievement.

Diary graph shows that students have experienced an increase after being given behavioral counseling with modeling techniques to increase self-achievement. The treatment was carried out in the experimental group only, the control group was only used as a comparison in the results of this study.

The pretest, posttest, follow-up 1 and follow-up 2 data have reached the Kolmogorov-Smirnov statistical value $>0.05$. Through the predetermined test criteria, that is, if the data has exceeded the $5 \%$ significance level, then all data are normally distributed. From the Levene's test, it can be seen that all data have a value> 0.05. Analysis of homogeneity test data using Lavene's test with a significance level of 5\%. Then it can be determined from these results that all data can be declared homogeneous. After being declared homogeneous, the next analysis was carried out by testing the hypothesis with the t-test.

Table 01 < Independent Samples Test >

\begin{tabular}{cccc}
\hline & $\mathrm{F}$ & Sig & $\mathrm{t}$ \\
\hline Pretes & .405 & .527 & .838 \\
\hline Posttes & .001 & .980 & 12.778 \\
\hline
\end{tabular}

Based on the table above, it can be seen that the pretest value data has $t=0.838$ and the posttest value data has $t=12,778$. The following data shows that "there is a significant difference in self achievement between before and after being given behavioral counseling with techniques".

Table $02<$ Kolmogorov-Smirnov >

\begin{tabular}{cccc}
\hline & $\mathrm{F}$ & $\mathrm{Sig}$ & $\mathrm{t}$ \\
\hline \multicolumn{1}{c}{ Posttes } & .001 & .980 & 12.778 \\
\hline Follow Up 1 & .000 & .997 & 13.136 \\
\hline Follow Up 2 & .011 & .915 & 12.518 \\
\hline
\end{tabular}

Based on the table above, posttest has a value of $t=12.778$, follow-up 1 has a value of $t=13.136$, and follow-up 2 has a value of $t=12.518$. From the results of the $t$-test, it is stated that the provision of treatment has a sustainable effect on the effect of student self achievement. 
Table $03<$ Normalized Score $>$

\begin{tabular}{cccc}
\hline \multicolumn{4}{c}{ Independent Samples Test } \\
\hline & $\mathrm{F}$ & Sig & $\mathrm{t}$ \\
\hline Gain Score & 2.787 & .099 & 18.166 \\
\hline
\end{tabular}

Based on the table above, it is found the normalized score gain data. The data gain score has obtained a test value of $t=18,166$. Followed by testing the effect size which resulted in ES $=4.16$. From the results of the ES, it can be interpreted in the predetermined criteria that is included in the very effective category. This shows that "there is an effect of behavioral counseling with modeling techniques to increase student selfachievement".

\section{Conclusion}

Based on the explanation of the research results and the above discussion, the following conclusions can be drawn: 1) There is a significant difference in self-achievement between before and after attending behavioral counseling with modeling techniques, 2) There is an effect of behavioral counseling with modeling techniques on self achievement of class X students. at SMK Negeri 1 Singaraja.

\section{Acknowledgment}

Thanks are given to God Almighty for providing fluency in completing this research and to those who have helped in completing this article.

\section{References}

Acquah, A. (2017). Implications of the Achievement Motivation Theory for School Management in Ghana : A Literature Review Implications of the Achievement Motivation Theory for School Management in Ghana: A Literature Review, 7 (5)(2224-5766), 10-14. Retrieved from https://www.researchgate.net/publication/316672421_Implications_of_the_Achievement_Motivati on_Theory_for_School_Management_in_Ghana_A_Literature_Review/link/590b62cda6fdcc5d421 ed1c6/download

Dharsana, I. K. (2019). Cognitive Counseling with Reframing Techniques to Intervene in Self Aggression. In Advances in Social Science, Education and Humanities Research (Vol. 382, pp. 62-64). Retrieved from https://www.mendeley.com/search/?query=Cognitive Counseling with Reframing Techniques to Intervene in Self Aggression\&adobe_mc_sdid=SDID\%3D0074CB94C27FDBBC3851BBCAA435435A\%7CMCORGID\%3D4D6368F454EC41940A4C98A6\%40AdobeOrg\%7CTS \%3D1594390868\&adobe_mc_ref=https\%3A\%2F\%2Fwww.mendeley.com\%2Fnewsfeed\%3Fsearch $\% 3$ Dresearch-papers

Dharsana, I. K., Paramartha, W. E., \& Sudarsana, G. N. (2018). Honest Development Characters Which Are Karma Phala Values. In International Conference on Technology and Educational Science. https://doi.org/10.4108/eai.21-11-2018.2282217

Dharsana, I. K., Suarni, N. K., Sudarsana, G. N., Paramartha, W. E., \& Mardiana, A.-B. T. counseling in developing C.-G. F. in adolescents. pdf. (2019). Cognitive-Behavioral Therapy Counseling in Developing Cross-Gender Friendship in Adolescents. Enfermeria Clinica, 30 (2), 206-208. Retrieved from https://www.sciencedirect.com/science/article/abs/pii/S1130862119304322?via\%3Dihub

Dharsana, K. (2017). Teori-teori Konseling. Singaraja: Undiksha Press.

Imran, A., Suarni, N. K., \& Darsana, I. K. (2019). Effectiveness of Behavior Conservation with Technical Modeling Through Lesson Learning to Increase Fun Characters for Others. Global Conferences Series : Sciences and Technology (GCSST), 1, 1-5. https://doi.org/10.32698/401

Jadad, A. R. (1998). Randomised Controlled Trials. London: BMJ Books. 
Mahendra, I. A., Darsana, I. K., \& Suarni, N. K. (2019). The Effectiveness of Behavioral Concept With Modeling Techniques to Improve Self Nurturance. Bisma The Journal of Counseling, 3(1), 18-24. https://doi.org/10.24036/18

Nabavi, R. T. (2014). Bandura's Social Learning Theory \& Social Cognitive Learning Theory. Reseachgate, (January 2012). Retrieved from https://www.researchgate.net/publication/267750204_Bandura's_Social_Learning_Theory_Social _Cognitive_Learning_Theory

Paramartha, W. E., Dharsana, I. K., \& Suarni, N. K. (2017). Gestalt Counseling with Dialog Game Techniques and Hipno Counseling Techniques for Self Achievement Pendahuluan. Bicma The Journal of Counseling, 1(1), 39-49. https://doi.org/10.23887/128322017

Skinner, B. F. (1976). About Behaviorism. New York: Vintage Books. Retrieved from https://bok.cc/book/2647463/9445c7

Zhou, M., College, D. S., Brown, D., \& College. (2015). Educational Learning Theories : 2nd Edition Educational Learning Theories. Retrieved https://oer.galileo.usg.edu/cgi/viewcontent.cgi?article=1000\&context=education-textbooks

Article Information (Supplementary)

Conflict of Interest Disclosures:

The authors declare that they have no significant competing financial, professional or personal interests that might have influenced the performance or presentation of the work described in this manuscript.

Copyrights Holder: <dharsana $><2021>$

First Publication Right: BISMA The Journal of Counseling

https://doi.org/10.xxxx/xxxxx

Open Access Article | CC-BY Creative Commons Attribution 4.0 International License.

Word Count: 